\title{
Adenomyoepithelioma of the Breast: An Intricate Diagnostic Problem
}

\author{
Fausto Catena Donatella Santini Salomone Di Saverio Luca Ansaloni Mario Taffurelli
}

Anesthesiological and Surgical Sciences DPT, St Orsola-Malpighi University Hospital Bologna, Italy

\section{Key Words}

Adenomyoepithelioma, breast - Breast cancer, differential diagnosis

\section{Summary}

Background: Adenomyoepithelioma (AME) of the breast is a biphasic very uncommon tumour with epithelial/ myoepithelial components. It can be easily recognised in an excised lesion, but it is more difficult to make a definitive diagnosis with needle biopsy. Case Report: We report the case of a 42-year-old woman who presented with a mass in her right breast. The patient underwent a fine needle aspiration, and a diagnosis of C5 carcinoma was made. Neoadjuvant treatment was proposed to the patient but she refused and was referred to a third level centre where a needle core biopsy was performed and a diagnosis suggestive of AME was made. Conclusion: If there is cytological atypia, AME may be confused with infiltrating ductal carcinoma in needle biopsies because of limited tissue sampling.

\section{Introduction}

Tumours with myoepithelial cell components have been recognised for some time within the salivary gland and, although rare, have also been described in the breast [1]. Adenomyoepithelioma (AME) of the breast is a biphasic tumour, morphologically and immunohistochemically identical to epithelial/myoepithelial cell carcinoma of the salivary gland [2]. It was first recognised in the breast by Hamperl [3]. Reports in

\author{
Schlüsselwörter \\ Adenomyoepitheliom, Brust · Brustkrebs, \\ Differentialdiagnose
}

\section{Zusammenfassung}

Hintergrund: Das Adenomyoepitheliom (AME) der Brust ist ein seltener, biphasischer Tumor mit epithelialen/myoepithelialen Anteilen. In einer Gewebeprobe ist ein AME leicht zu diagnostizieren, anhand einer Nadelbiopsie ist die sichere Diagnosestellung jedoch erschwert. Fallbericht: Wir berichten über den Fall einer 42-jährigen $\mathrm{Pa}$ tientin, die mit einem Knoten in der rechten Brust vorstellig wurde. Die Feinnadelbiopsie ergab ein C5-Karzinom. Der Patientin wurde eine neoadjuvante Therapie empfohlen, welche sie jedoch ablehnte. Daraufhin wurde sie an ein spezialisiertes Zentrum überwiesen, wo eine Nadelbiopsie durchgeführt wurde und die Diagnose eines möglichen AME gestellt wurde. Schlussfolgerung: Bei zytologischern Atypien in Nadelbiopsien kann es auf Grund der geringen Gewebemenge zur Verwechslung eines AME mit einem invasiven Duktalkarzinom kommen.

the literature are primarily single case reports or small series. Unlike pure myoepithelial carcinomas, AMEs of the breast feature proliferation of both the luminal glandular component and myoepithelial cells. Although generally considered to be benign, malignant and metastatic AMEs have been reported; it seems that no less than $50 \%$ of the published cases showed an aggressive behaviour [4]. Metastases have been described in 5 reports, with sites including ribs, lumbar spine, bones, lung, brain, regional lymph nodes, and jaw [5]. Although AME of

\begin{tabular}{ll}
\hline KARGER & @ 2008 S. Karger GmbH, Freiburg \\
Fax +49 7614520714 & Accessible online at: \\
$\begin{array}{l}\text { E-mail Information@Karger.de } \\
\text { www.karger.com }\end{array}$ & www.karger.com/brc
\end{tabular}


the breast can be easily recognised in an excised lesion, it is more difficult to make a definitive diagnosis with a core needle biopsy. If there is cytological atypia, it may be confused with infiltrating ductal carcinoma in a core needle biopsy because of limited tissue sampling [6]. We present a case of atypical AME and discuss the diagnostic and therapeutic problems.

\section{Case Report}

A 42-year-old woman presented with a mass in her right breast, which she had discovered 1 month ago. She was referred for bilateral mammography and right breast ultrasound. The patient stated that she had a normal mammogram 1 year prior to this presentation and had no prior history of breast abnormalities. Her past medical history was not significant. She had no family history of breast cancer. On physical examination, a $5 \times 4-\mathrm{cm}$ mobile mass was palpated in the right inferior external quadrant. There was a normal nipple without dimpling of the overlying skin or nipple discharge. No axillary masses or lymph nodes were palpated bilaterally. The left breast was unremarkable. Mammography of the right breast showed a $5 \times 4-\mathrm{cm}$, dense, oval mass with well defined margins in the subareolar area (fig. 1). An ultrasound of the right breast showed a $5 \times 4-\mathrm{cm}$ mass with heterogenous echogenicity $2 \mathrm{~cm}$ from the areolar margin. The patient underwent a fine needle aspiration of the right breast mass 2 months later at another institution with a diagnosis of C5 carcinoma. Neoadjuvant treatment was proposed to the patient but she refused. She was referred to a third level centre where a needle core biopsy was performed. The pathologic evaluation showed a fibroepithelial lesion with duct hyperplasia and microcalcification, and a diagnosis suggestive of AME was made. The patient underwent mass excision without axillary node dissection. Frozen section examination was negative for malignant tumour. On sectioning, the mass measuring $4 \times 4 \mathrm{~cm}$ was solid, well circumscribed, with lobulated pattern. On histology, the tumour showed aggregated nodules consisting of compact proliferation of epithelial and myoepithelial cells arranged in cords, gland or irregular aggregates separated by bands of fibrovascular stroma. Ductal epithelial and myoepithelial hyperplasia was prominent, and in some areas the clear cell myoepithelial hyperplasia displaced glandular structures. Apocrine epithelium was evident in some glands, and spindle myoepithelial cells were also present. Cytologic atypia of the epithelial and myoepithelial components was observed. Immunohistochemistry confirmed the combination of a dual proliferative type of cells with evident positivity for alpha-smooth muscle actin and S-100 protein for the myoepithelial cells. A diagnosis of AME with atypia was made.

\section{Discussion}

AME of the breast is a biphasic tumour, morphologically and immunohistochemically identical to epithelial/myoepithelial cell carcinoma of the salivary gland [2]. Breast AME malignancies are very uncommon; they have been reported in women aged $27-80$ years (mean age 60 years) [6]. These neoplasms can be peripheral or centrally located near the areola with a palpable nodule [4]. Grossly, AMEs are well circumscribed, firm to hard, and nodular, but they may be soft or have ill-defined margins, and occasionally contain small cysts. The tumour size varies from 0.5 to $5 \mathrm{~cm}$ (median size, $1.5 \mathrm{~cm}$ )

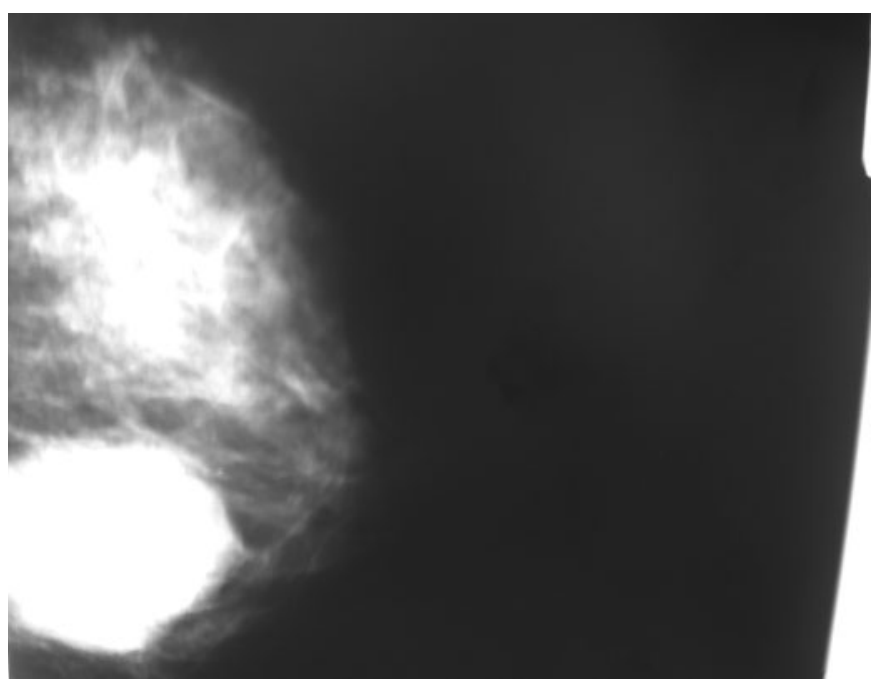

Fig. 1. Mammography of the right breast showed a $5 \times 4-\mathrm{cm}$, dense, oval mass with well defined margins in the subareolar area.

[7]. Histologically, benign AMEs have a distinctive and balanced proliferation of epithelial elements composed of round to oval or tubular glands admixed with sheets of polygonal myoepithelial cells with clear vacuolated cytoplasm. The epithelial cells have scanty cytoplasm and dark hyperchromatic nuclei with infrequent mitoses. The myoepithelial cells vary from polygonal to spindle cell myoid growth pattern and rarely exhibit atypia [7]. Malignancy can develop in the epithelial component, the myoepithelial component, or in both components. The present case indicates an important diagnostic problem associated with AME. Needle biopsy was positive for C5 carcinoma, and a neoadjuvant treatment was proposed to the patient, which she refused. It is important to underline that the fine needle aspiration cytology as a breast diagnostic tool should be challenged: in some countries this procedure is no longer recommended because of a lack of adequate training facilities.

The patient was then referred to a third level centre, and the new pathologic evaluation suggested a possible AME. AME with cytologic atypia may be confused with infiltrating ductal carcinoma in a core needle biopsy because of limited tissue sampling. However, abundant clear cytoplasm in the tumour cells may suggest the possibility of an unusual tumour. In contrast to carcinomas composed of a uniform population of malignant epithelial cells, AME exhibits biphasic cellular elements of ductal and myoepithelial cells arranged in a characteristic tubular and solid pattern. Additional studies should include immunohistochemistry to demonstrate a biphasic cellular pattern in an AME. In our patient, immunohistochemistry, the positivity for alpha-smooth muscle actin and S-100 protein confirmed the exuberant coexistence of myoepithelial cells within the proliferative lesion. Immunohistochemistry is very useful in confirming the diagnosis. The epithelial elements stain with antibodies to cytokeratins and carcinoembryonic antigen. The myoepithelial cells stain with S100 and actin. 
More recently, $\mathrm{C} 10$ and p63 have been used as reliable markers of myoepithelial phenotype [5]. The prognosis of AME is usually good. Local recurrences can be evident in the case of incomplete excision [4]. AMEs exhibit a characteristic multinodular growth pattern with surrounding satellite nodules, features that contribute to local recurrence even in the more common benign adenomyoepithelial tumours owing to incomplete excision of the tumour [8].

There are no well defined histological criteria for malignancy because of the rarity of the lesion [8]. The malignant tumours described in the literature contain necrosis, a spindle cell component, local invasion, cytological atypia, and increased mitotic figures of more than 5/10 high power fields (HPF) [3, 4]. Up to now, 135 cases are reported in the literature; the review of all these cases confirmed the difficult and intricate differential diagnosis of AME from malignant lesions. In most of the cases reviewed, AME can mime a malignant carcinoma in its mammographic and ultrasound appearance, as well as in the aspiration cytology and immunohistochemistry features. Every physician must be aware of this diagnostic problem.

\section{References}

1 Tavassoli FA: Myoepithelial lesions of the breast. Myoepitheliosis, adenomyoepithelioma, and myoepithelial carcinoma. Am J Surg Pathol 1991;15 554-568.

2 Seifert G: Are adenomyoepithelioma of the breast and epithelial-myoepithelial carcinoma of the salivary glands identical tumours? Virchows Arch 1998;433:285-288.

3 Hamperl H: The myothelia (myoepithelial cells). Normal state; regressive changes; hyperplasia; tumors. Curr Top Pathol 1970;53:161-220.
Foschini MP, Eusebi V: Carcinomas of the breast showing myoepithelial cell differentiation. A review of the literature. Virchows Arch 1998;432: 303-310.

5 Ahmed AA, Heller DS: Malignant adenomyoepithelioma of the breast with malignant proliferation of epithelial and myoepithelial elements: a case report and review of the literature. Arch Pathol Lab Med 2000;124:632-636.

6 Rosen PP: Adenomyoepithelioma of the breast. Hum Pathol 1987;18:1232-1237.
7 Harigopal M, Park H, Chen X, Rosen PP: Pathologic quiz case: a rapidly increasing breast mass in a postmenopausal woman. Malignant adenomyoepithelioma. Arch Pathol Lab Med 2004;128:235-236.

8 Loose JH, Patchefsky AS, Hollander IJ, Lavin LS, Cooper HS, Katz SM: Adenomyoepithelioma of the breast. A spectrum of biologic behavior. Am J Surg Pathol 1992;16:868-876. 